\title{
BİR BİYOGRAF OLARAK ALİ RIZA ÖNDER VE HAZIRLADIĞI BIYYOGRAFILER
}

\author{
Hava GAYGUSUZ* - Cavit GÜZEL**
}

\begin{abstract}
Özet
Biyografiler, toplumda belli özellikleri ile ön plana çıkan kişiler hakkında derli toplu bilgiler edinebileceğimiz edebi bir türdür. Bu türde biyografisi hazırlanan kişilerin merak edilen yönleri hakkında bilgi sahibi olunabilir ya da yeni özellikleri keşfedilebilir. Bu çalışma 1918-1994 yılları arasında yaşamış hukukçu olan ancak halkbilimci ve dil bilimci kimliği ile de adından söz ettiren değerli kültür insanı Ali Rıza Önder'in biyograf vasfını tanıtmayı amaçlamaktadır. Çalışmada ilk olarak biyografi terimi ve Ali Rıza Önder hakkında kısa bilgi sunulacaktır. Ardından biyograf olarak nitelendirilebilecek çalışmalara imza atmış olan Önder'in çeşitli dergi ve gazetelerde yayımladı̆̆ arkeolog, dil bilimci, din âlimi, gazeteci, halk bilimci, halk ozanı, hukukçu, öğretmen, siyasetçi, şair ve ziraatçı gibi birçok farklı meslek grubuna mensup kırk yedi şahsiyetin biyografi çalışması tanıtılacak ve kronolojik sıra ile aktarılacaktır. Ali Rıza Önder'in biyografisini hazırlayacağ hazırladığı biyografilerde ortaya koyduğu usul incelenecektir.
\end{abstract}

Anahtar Kelimeler: Ali Rıza Önder, biyograf, biyografi, Türk Folklor Araştırmaları Dergisi.

\section{ALİ RIZA ÖNDER AS A BIOGRAPHER AND THE BIOGRAPHIES HE PREPARED}

\begin{abstract}
Biographies are a literary genre in which we can get tidy information about people who come to the fore with certain characteristics in the society. It is possible to learn about the curious aspects of the people whose biographies are prepared or to discover new features. This study aims to introduce the biographer qualification of Ali Riza Önder, a valuable cultural person who lived between 1918-1994 and made a name with his folklorist and linguist identity. In our study, firstly, a brief information about biography term and about Ali Riza Önder will be presented. Afterwards, biography work of forty-seven individuals consisting of many different professional groups such as archaeologist, linguist, scholar, journalist, folklorist, minstrel, jurist, teacher, politician, poet and agronomist that are published by Önder in various newspapers and magazines, who has such undersigned works that make it possible for him to be described as a biographer, will be cited in chronological order and with names. The method that Ali Riza Önder put forward in his biographies will be examined by trying to determine what may be the factors that are effective in his selection regarding his biography works.
\end{abstract}

Keywords: Ali Rıza Önder, biographer, biography, Türk Folklor Araştırmaları journal.

* Yüksek Lisans Öğrencisi, Amasya Üniversitesi, Sosyal Bilimler Enstitüsü, Türk Dili ve Edebiyatı Anabilim Dalı

e-posta: gaygusuzhavva@gmail.com

** Dr. Öğr. Üyesi, Amasya Üniversitesi, Fen-Edebiyat Fakültesi Türk Dili ve Edebiyatı Bölümü

e-posta: cvtgzl40@gmail.com 


\section{Giriş}

Biyografi, Yunanca "bios (hayat)" ve "graphien (yazmak)" sözlerinden oluşmuştur. Literatürde biyografi, biyografya, yaşam öyküsü ve terceme-i hâl olarak da geçen bu sözcüğün en yaygın kullanımı biyografidir (Çetin 2012: 143). Biyografiler toplumda belli yönleriyle ön plana çıkan kişilerin, hayatları hakkında bilgi sahibi olabileceğimiz yazınsal bir türdür. Kültürel kimliğin kuşaklara aktarımını kolaylaştıran ve geleceğe kaynaklık eden bu türü hazırlayanlara ise biyograf denir. Biyograf kelimesi Türkçe Sözlük’te hayat hikâyesi yazarı olarak geçmektedir (2005: 288).

Türk kültür hayatına hazırladığı biyografilerle katkı sağlayan önemli araştırmacılardan biri de Ali Rıza Önder'dir. 1918 yılında Kayseri'nin Turan köyünde dünyaya gelen Ali Rıza Önder; ilkokulu, ortaokulu ve liseyi Kayseri' de tamamlamıştır. 1939 yılında başladığ 1 Ankara Üniversitesi Hukuk Fakültesinden 1942'de mezun olmuştur. 1939 yılında Erciyes dergisinde kültür yayın faaliyetlerine başlayan Önder, sonraki yıllarda Türk Folklor Araştırmaları, Yeni Erciyes, Türk Düşüncesi, Filiz, Yeni Adam, Türk Dili, Sivas Folkloru, Ziya Gökalp, Türk Folkloru, 4 Eylül Ortak Kitap, Kemalist Ülkü, Millî Kültür, Littera Edebiyat Yazıları ve Çağrı adlı dergiler ile çeşitli gazetelerde yazılarını yayımlamıştır. Hukukçu kimliğinin yanı sıra Türk dili üzerine yaptığı çalışmalarla da ön plana çıkan Ali Rıza Önder, 12 Haziran 1960 tarihinde Türk Dil Kurumu üyeliğine 1966'da ise TDK Onur Kurulu üyeliğine seçilmiştir (Tan 2019: 28-29). 9 Aralık 1969 tarihinde Türk Folklor Araştırmaları Kurumuna üye olan Önder, aynı kurumun Yönetim Kurulu ve Denetleme Kurulu üyeliğini de yapmıştır (Nasrattınoğlu 2019: 17). Çok yönlü bu kültür insanının Yaşayan Anadolu Efsaneleri (1955), Yasa Dili Sözlüğü (1966), Hukuk Araştırmaları (1968), Kayseri Basın Tarihi (1972) adlı kitapları ile yukarıda adı geçen dergi ve gazetelerde beş yüzü aşkın yazısı bulunmaktadır. Bu yazılar içerisinde hazırladığı biyografi çalışmaları azımsanmayacak niceliktedir. Ali Rıza Önder'in çeşitli dergi ve gazetelerde yayımlamış olduğu bu biyografi çalışmaları kronolojik olarak şöyledir:

\section{Ali Rıza Önder’in Hazırladığı Biyografiler:}

\section{1. Şerife Soykan ${ }^{1}$}

1879 yılında Kayseri'nin Turan köyünde doğmuş olan Şerife Soykan yörede; Şerife Hala, Kara Şerif ve Esmer Hatun olarak anılmaktadır. Ali Rıza Önder, Erciyes dergisinin 26-27. sayısında "Kadın Halk Şairi Şerife Soykan (1879-1945)" adlı çalışmasını Şerife Soykan'ın vefatından sonra yayımlamıştır. Çalışmada Soykan'ın mizacına da değinen Önder, aralarında geçen konuşmaların kısa özetine yer vermiştir. Son kısımda ise "Arl" başlıklı bir deyişini aktarmıştır (Önder: 1945: 15-18).

\footnotetext{
${ }^{1}$ Ali Rıza Önder, Türk Dili dergisinin 209. sayısında “Kayseri'li Esmer Hatun ve Deyişleri”'(1969) ve Türk Folklor Araştırmaları dergisinin 324. sayısında "Halk Ozanı Şerife Soykan”(1976) adlı çalışmalarda da Şerife Soykan'ın biyografik hayatına ve deyişlerine yer vermiştir.
} 


\section{Hamdi Öztosun}

Asıl adı Hamdi Öztosun olan âşık, Osmancıkoğlu adı ile tanınmıştır. Erciyes dergisinin 40-41. sayısında "Halk Şairi Osmancıkoğlu (1908-1945)" başlığı ile yayımlanan yazıda âşığın kısa biyografisi ile "Kıtlık Destanı" ve "Erzincan Destanı" adlı şiirlerinden bölümler yer almaktadır (Önder 1946: 24).

\section{Cafer Uçak}

Şiirlerinde Âşık İmam, Yılmaz ve İmamî mahlaslarını kullanan Cafer Uçak ile bir tren seyahatinde karşılaştıklarını belirten Önder, bu şahsiyeti "Elbistanlı Âşık Imam" adı ile Erciyes dergisinin 51. sayısında tanıtmıştır. Şairin biri yedi diğeri iki dörtlükten oluşan şiirlerine de yer vermiştir (Önder 1947: 7).

\section{4. Âşıık Ali Huzurî Coşkun}

XX. yüzyıl âşıklarından olan Ali Huzurî Coşkun, Yusufelili âşıklardandır. Âşı̆̆ın ölüm yıl dönümü dolayısıyla kaleme alınan "Âşık Ali Huzurî Coşkun" başlıklı bu çalışma, Türk Folklor Araştırmaları dergisinin 40. sayısında yayımlanmıştır. Önder, âşığın vefat etmeden önce yazmış olduğu son şiiri ve daha önce yayımlanmadığını belirttiği dört şiirini de aktarmıştır (Önder 1952: 639-640).

\section{Mustafa Hayri Efendi}

Önder, Kayseri bölgesinin yetiştirdiği bilginler arasında saydığı Mustafa Hayri Efendi'nin biyografik hayatını İstiklâl gazetesinde "Şeyhülislam Hayri Efendi" başlığı ile yayımlamıştır. "Türk Meşhurları" adlı eserde yanlış olarak verilen ölüm yılını mezar taşını okuyarak 1922 olduğunu tespit etmiştir. Ayrıca mezar taşındaki yazı ile oğlu için söylediği nasihat de çalışmada yer almaktadır (Önder 1953: 2).

\section{Hüseyin Kâzım Kadri}

“Hüseyin Kâzım Kadri ve Türkçe Sözlüğü” adlı çalışma, Türk Dili dergisinin 53. sayısında yayımlanmıştır. Önder bu makalesinde Türk kültürüne katkıları bulunan devlet adamı, gazeteci, ziraatçı H. Kâzım Kadri'nin ailesi, çalışma hayatı ve "Türk Lügati” adlı eseri üzerinde durmuştur. Önder ayrıca, Alaaddin Gövsa, Hüseyin Cahit ve İsmail Kara'nın da bu çok yönlü kültür insanı ile ilgili değerlendirmelerini aktarmıştır. (Önder 1956: 54-60).

\section{Feramus Uçaraveı}

Ali Rıza Önder, Hâkimiyet gazetesinin 20 Şubat 1957 tarihinde çıkan nüshasında "Feramus Uçaravcı" başlığı ile yer alan yazısında adı geçen âşığın hayatına kısaca değindikten sonra öğüt içeren bir şiirine yer vermiştir (Önder 1957: 2, 4).

\section{Sadri Maksudî Arsal}

Hukukçu, siyasetçi ve düşünür Sadri Maksudî Arsal, Kazan Türklerindendir. Önder, Ankara Hukuk Fakültesinden hocası Arsal'ın 1957 y1lında vefat etmesi üzerine aynı yıl Haziran ayında Türk Düşüncesi dergisinin 7. sayısında "Sadri Maksudî Arsal" adı ile bir anma yazısı kaleme almıştır. Bu yazıda Arsal'ın aile, eğitim, çalışma ve siyasi hayatını kısaca aktarmıştır. Basılmış eserlerinin de 
listesini veren Önder, onun Türkçülük ile ilgili düşüncelerinin daha iyi anlaşılması için yazılarından kısa bölümler sunmuştur (Önder 1957: 52-56).

\section{9. Âşık Mahfî}

Asıl adı Ali olan âşık, Ürgüp'ün kalem şairleri arasındadır. Önder, Ürgüp dügün geleneklerinden biri olan "nahıl övmesi"ni vaktiyle Mahfî tarafından söylendiğini yazıda ifade etmiştir. Adı geçen çalışma, "Ürgüplü Âşık Mahfi” adı ile Türk Folklor Araştırmaları dergisinin 99. sayısında yayımlamıştır. Önder, âşı̆̆ın sanatı hakkında fikir sahibi olunması için ise üç şiirini aktarmıştır (Önder 1957: 15731574).

\section{Memiş Şahin}

Ali Rıza Önder, 10 Mart 1939 tarihinde Ürgüp'te doğan saz şairi Memiş Şahin'i tanıtmak amacıyla bu yazıyı kaleme almıştır. Türk Folklor Araştırmaları dergisinin 105. sayısında "Ürgüplü Memiş Şahin" adı ile yayımlanan çalışmada adı geçen saz şairinin sel felaketi üzerine yazmış olduğu "On Bir Haziran Destanı" ve “On Dört Haziran Destanı" adlı şiirlerine yer vermiştir (Önder 1957: 1680-1681).

\section{Basri Gocul ${ }^{2}$}

"Oğuzlama ve Basri Gocul” adlı çalışma Türk Folklor Araştırmaları dergisinin 108. sayısında yayımlanmıştır. Önder, Dede Korkut hikâyelerini nazma çeken ve bunları Oğuzlama olarak adlandıran Gocul'u tanıtmak için bu yazıyı kaleme almıştır. Fikir edinilmesi için ise Oğuzlama'dan bir bölüm sunmuştur (Önder 1958: 1727-1728).

\section{Tahir Yavuzaslan}

"Kemahlı Tahir ve Divanı" adlı çalışma Türk Folklor Araştırmaları dergisinin 121. sayısında yayımlanmıştır. Mutasavvıf bir şair olan Tahir'in el yazması divanını inceleyen Önder, onu tanıtarak divanından bölümler aktarmıştır (Önder 1959: 1969-1970).

\section{Kazım Yedekçioğlu}

“Kayseri Halkbilimi ve Kâzım Yedekçioğlu” başlıklı bu çalışma, Türk Folklor Araştırmaları dergisinin 153. sayısında yayımlanmıştır. Önder, asıl mesleği öğretmenlik olan Kâzım Yedekçioğlu'nun Kayseri halkbilimi ile ilgili çalışmalarıyla Kayseri'de tanındığından bahsetmiştir. Ayrıca onu daha geniş çevrelere tanıtmak amacıyla bu biyografi çalışmasını hazırladığını ifade etmiştir. Yedekçioğlu'nun; aile, eğitim ve çalışma hayatına değindikten sonra onun Erciyes ve Yeni Erciyes dergilerinde yayımlanmış yazılarının listesini vermiştir (Önder 1962: 2687-2688).

\section{Vehbi Cem Aşkun}

Önder, Sivas folkloru denince akla gelen ilk isimlerden olduğunu belirttiği Vehbi Cem Aşkun'u "Vehbi Cem Aşkun ve Çalışmaları" adı ile Türk Folklor

2 “Oğuzlama ve Basri Gocul” adlı bu çalışma Filiz dergisinin 5. sayısında da yayımlanmıştır. 
Araştırmaları dergisinin 160. sayısında yayımlamış olduğu makale ile tanıtmıştır. Yazının yayımlandığı yıl Aşkun'un "Kader" adlı bir romanının yayımlandığı görülmektedir ancak bu eserin Önder'in araştırmacıyı tanıtmasında etkili olup olmadığına dair bir bilgiye rastlanmamaktadır. Çalışmada ayrıca yazarın "Sivas Folkloru" adlı eserinden de bahsedilmiştir (Önder 1962: 2887-2888).

\section{5. Ömer Asım Aksoy}

Ali Rıza Önder, halk dili konusunda önemli çalışmalardan biri olan "Gaziantep A ̆gzl" adlı üç ciltlik eserin sahibi Ömer Asım Aksoy'u "Ömer Asım Aksoy" başlığ1 ile hazırladığ 1 yazıda tanıtmıştır. Biyografi, Türk Folklor Araştırmaları dergisinin 165. sayısında yayımlanmıştır. Çalışmada, bu eserin içeriğinden ve Aksoy'un Türk Dil Kurumuna hizmetlerinden söz edilmiştir (Önder 1963: 3032-3033).

\section{6. Şevket Beysanoğlu}

"Şevket Beysanoğlu" adı ile yayımlanan makale, Türk Folklor Araştırmaları dergisinin 179. sayısında yer almaktadır. Önder, bu yazısında Diyarbakır folklorunun önemli isimlerinden hukukçu Şevket Beysanoğlu'nun aile, okul ve çalışma hayatından söz etmiş, ardından basılmış ve basılacak eserlerini listelemiştir (Önder 1964: 3426-3427).

\section{Mehmet Önder}

Ali Rıza Önder, 8 Nisan 1964 tarihinde Millî Eğitim Bakanlığı Eski Eserler ve Müzeler Genel Müdürlügüne atanmış olan Mehmet Önder'i Türk Folklor Araştırmaları dergisinin 182. sayısında "Mehmet Önder ve Konya Halkbilimi" adlı yazı ile ele almıştır. Yazıda; Önder'in aile, eğitim ve çalışma hayatından bahsedilmiş ardından da yayımlanmış eserlerinin listesi verilmiştir. Konya halkbilim çalışmaları açısından önemli isimlerden olan Mehmet Önder'in bu tarihte incelenmesinde yeni atandığı görevinin etkisinin olabileceği değerlendirilebilir (Önder 1964: 3514-3516).

\section{Mehmet Fahrettin Kırzıoğlu}

"Mehmet Fahrettin Kırzıoğlu” adlı yazı, Türk Folklor Araştırmaları dergisinin 185. sayısında yayımlanmıştır. Yazıda; Kırzıoğlu'nun aile, eğitim ve çalışma yaşamından bahsedilmiş devamında yazılarının yayımlandığı dergiler ile basılmış eserleri aktarılmıştır. Doğu Anadolu Bölgesi ve Azerbaycan halk bilimi çalışmaları açısından önemli isimlerden biri olan Kırzıoğlu ile ilgili bu yazının yayımlandığı yıl araştırmacının "Her Bakımdan Türk Olan Kürtler" adlı kitabı da yayımlanmıştır. Bu biyografi çalışması ile Kırzıoğlu'nun eserinin yayımlanma yılı arasındaki ilişkinin tesadüfî olduğu görülmektedir (Önder 1964: 3595-3597).

\section{Hikmet Dizdaroğlu}

Önder, edebiyat tarihi ve halk şairleri üzerine yaptığı çalışmalarla tanınan Hikmet Dizdaroğlu'na, Türk Folklor Araştırmaları dergisinin 190. sayısında "Hikmet Dizdaroğlu” başlıklı yazıyla yer ayırmıştır. Dizdaroğlu'nun; ilk olarak aile, eğitim ve çalışma hayatına yer veren Önder, ardından erken yaşta yazı hayatına atılan bu araştırmacının çeşitli dergilerde yayımlanmış yazılarının listesini vermişstir. Son 
kısımda ise basılmış ve basılacak eserlerinin künyelerini aktarmıştır (Önder 1965: 3737-3738).

\section{Ali Rıza Efendi}

Önder, "Yeni Yazı" ve "Okuma-Yazma" adlı eserleri ile tanınan Yanyalı Ali Rıza Efendi ile ilgili biyografik çalışmaya Türk Dili dergisinin 166. sayısında "Betikçi Ali Rlza" adı ile yer vermiştir. Önder, bahsi geçen kişi hakkında elde yeterli bilgi bulunmadığını var olan bilgilerin de yanlış olduğunu belirterek Ali Rıza Efendi hakkındaki bu çalışmayı hazırlama amacını ifade eder. Önder çalışmasının son kısımda arşivdeki sicil dosyasından aldığı Ali Rıza Efendi hakkındaki kaydı aktarmıştır (Önder 1965: 707-708).

\section{Cahit Öztelli}

Cahit Öztelli, 1917 yılında Erzincan'da doğmuştur. Âşık edebiyatı üzerine yaptığı çalışmalarla Türk folkloruna önemli katkıları olmuştur. Ali Rıza Önder, Türk Folklor Araştırmaları dergisinin 193. sayısında "Cahit Öztelli" başlığı ile hazırladığı yazıda araştırmacının hayatına, basılmış ve basılacak eserlerinin listesine yer vermiştir. Ayrıca bu yazıda Cahit Öztelli'nin halkbilimi konularını içeren 112 makalesinin ismi de bir liste halinde sunulmuştur. (Önder 1965: 38193820).

\section{2. İsmayıl Hakkı Baltacıoğlu}

Ali Rıza Önder, Türk Folklor Araştırmaları dergisinin 196. sayısında İsmayıl Hakkı Baltacıoğlu'nun biyografisine yer vermiştir. "Ísmayıl Hakk Baltacıoğlu”" adlı yazıda Önder, Baltacıŏlu'nun yayımladığ "Pedagojide Ihtilal" adlı eserden dolayı yazarın savunmasının istendiğini gazeteden öğrendiğini belirtir. Ardından bu çok yönlü âlimin yaşantısını ve yayınlarını vermeyi uygun gördüğünü ifade eden Önder, Baltacıoğlu'nun yaptığı görevleri yıllara göre siraladıktan sonra yayımlanmış eserlerini de konularına göre sıralamıştır (Önder 1965: 3903-3905).

\section{Yunus Bekir ${ }^{3}$}

Kayseri'de ilk Türkçe gazete olarak yayın hayatına başlayan Erciyes'in sahibi ve sorumlu yönetmeni Yunus Bekir, Ali Rıza Önder'in amcasıdır. "Yunus Bekir" adı ile Filiz dergisinin 16. sayısında yayımlanan yazıda Kayseri basınında emeği yadsınamaz olan bu şahsiyetin aile, çalışma, basın ve sürgün yaşantısına yer verilmiştir (Önder 1966: 7, 11).

\section{Galip Öcal}

“Öğretmen Galip Öcal” adlı yazı Filiz dergisinin 18. sayısında yayımlanmıştır. Önder, bu yazısında kırk altı yıllık kesintisiz köy öğretmenliği görevinden emekliye ayrılan bir dönem kendisinin de hocalığını yapmış olan Öcal'ın örnek hayatına yer vermiştir. (Önder 1966: 3, 9).

\section{Hasan Turan}

\footnotetext{
${ }^{3}$ Ali Rıza Önder, Yeni Adam dergisinin 821. sayısında yer alan "Yunus Bekir'in Anıları" başlıklı çalışmada da Yunus Bekir'in biyografik hayatı ile ilgili bilgi aktarmıştır.
} 
"Popüler Türküler Şairi Hasan Turan" adlı yazı Türk Folklor Araştırmaları dergisinin 200. sayısında yer almaktadır. Önder, şairin hayatı hakkında bilgi verdikten sonra "Ana Beni Eversene" ve "Zügüurtlük” adlı bestelenmiş şiirlerine de yazıda yer vermiştir. (Önder 1966: 4031-4032).

\section{Abdülkadir Sarıkelle}

Kayseri'de çıkan "Cuma" adlı gazetenin sahibi hukukçu, araştırmacı Abdülkadir Sarıkelle'nin vefatının yirminci yıl dönümü dolayısıyla hazırlanmış bir biyografidir. Filiz dergisinin 20. sayısında "Abdülkadir Sarlkelle (1875-1946)" başlığı ile yayımlanmıştır. Yazıda Sarıkelle'nin aile, eğitim, çalışma ve basın hayatına yer verilmiştir (Önder 1966: 5, 11).

\section{Ahmet Hilmi Kalaç}

Önder, Kayseri basın tarihinin önemli isimlerinden biri olan Ahmet Hilmi Kalaç'a Filiz dergisinin 22. sayısında "Ahmet Hilmi Kalaç” adlı çalışma ile yer ayırmıştır. Çalışmada Kalaç'ın aile, eğitim, siyasi hayatına ve basın faaliyetlerine yer verilmiştir. Esasen yazı Kalaç, vefat etmeden önce kaleme alınmış ve dergiye gönderilmişse de ancak vefat ettikten sonra yayımlanabilmiştir. (Önder 1966: 3, 9, 11).

\section{Mustafa Adil Özer}

"Mustafa Adil Özer" başlı̆̆ı ile Türk Folklor Araştırmaları dergisinin 207. sayısında yayımlanan yazıda Önder, halkbilimi üzerine araştırma ve incelemeleriyle tanınan Özer'in aile, eğitim ve çalışma hayatına yer vermiştir. Özer'in halkbilimi ile ilgili çalışmalarının yayımladığı dergilerden söz ettikten sonra yazarın yayımlanmış kitap ve yazılarının listesini vermiştir (Önder 1966: 4214-4215).

\section{Naki Tezel}

Önder, Türk Folklor Araştırmaları dergisinin 209. sayısında "Naki Tezel" başlıklı yazısı ile halkbilim alanına Mehmet Halit Bayrı'nın öncülügünde başlamış olan ve otuz yılı aşkın süredir bu yolda ilerleyen Tezel'in yayımlanmış eserlerinin listesi ile çeşitli dergi ve gazetelerde yer alan yazılarının isimlerini tarihleriyle vermiştir (Önder 1966: 4267-4268).

\section{Findıkoğlu Ziyaeddin Fahri}

Türk Folklor Araştırmaları dergisinin 212. sayısında "Ord. Prof. Dr. Fındıkoğlu Ziyaeddin Fahri" adı ile kaleme alınan yazıda Türkiye'de folklor çalışmalarının öncülerinden sayılan Fındıkoğlu'nun hayatı ile çeşitli dergi ve gazetelerde yayımlanmış yazılarının künyeleri aktarılmıştır (Önder 1967: 4353-4355).

\section{Ahmet Kutsi Tecer}

Türk Folklor Araştırmaları dergisi, 218. sayısını 23 Temmuz 1967 tarihinde vefat eden folklor araştırmacısı, eğitimci, şair Ahmet Kutsi Tecer'e ayırmıştır. Behçet Kemal Çağlar, Eflatun Cem Güney ve Ali Rıza Önder'in de aralarında olduğu on altı kişi Tecer ile ilgili anma yazısı hazırlamıştır. Önder, "Ahmet Kutsi Tecer 
(1901-1967)" başlıklı yazısında Tecer'in eğitim ve çalışma hayatından, üyesi olduğu kuruluşlardan, yayımlanmış kitap ve yazılarından söz etmiştir (Önder 1967: 4515-4517).

\section{Ahmet Şükrü Esen}

Ali Rıza Önder tarafindan hazırlanan “Ahmet Şükrü Esen (1893-1944)” adlı makale Türk Folklor Araştırmaları dergisinin 222. sayısında yayımlanmıştır. Önder; araştırmacı, hukukçu, siyasetçi ve halkbilim derleyicisi olan Esen hakkında yapılan ilk çalışmaların Ziyaeddin Fındıkoğlu tarafından yapıldığına dikkat çekmiștir. Ayrıca Ahmet Șükrü Esen'in derlediği halkbilim malzemelerinin akıbeti ile ilgili düşüncelerini de aktarmıştır (Önder 1968: 4631-4633).

\section{Veysel Arseven}

Türk Folklor Araştırmaları dergisinin 232. sayısında "Veysel Arseven" başlığı ile hazırladığı çalışmasında Önder, Gagavuz Türklerinden olan Türk halk müziği araştırmacısı Arseven'in; aile hayatı, eğitimi, çalışmaları hakkında bilgi vermiştir. Önder, yakında yayımlanacak olan Meydan Larousse adlı ansiklopedinin halk müziği ve halk çalgıları maddelerinin Veysel Arseven tarafından hazırlanacağının da haberini vermiştir. (Önder 1968: 5120-5122).

\section{4. Şükrü Elçin}

"Şükrü Elçin" adlı çalışma Türk Folklor Araştırmaları dergisinin 236. sayısında yayımlanmıştır. Türk kültürü özellikle Türk halk edebiyatı çalışmalarıyla tanınan Elçin'in aile hayatı, eğitimi ve çalışmalarına değinen Önder, onun çeşitli dergilerde yayımlanan halkbilimi konulu yazılarının künyeleri aktarmıştır (Önder 1969: 5232-5233).

\section{5. Şerif Baykurt}

Türk Folklor Araştırmaları dergisinin 245. sayısında "Şerif Baykurt" adlı bir çalışma yayımlanmıştır. Resim öğretmeni olan Baykurt, halk dansları ile ilgili çalışmalarıyla ön plana çıkmıştır. Önder yazısında, 1968 yılında Millî Folklor Enstitüsü Müdür Yardımcılığına atanan Baykurt'un çeşitli dergi ve gazetelerde yayımlanan yazılarının isimlerini de aktarmıştır (Önder 1969: 5475-5476).

\section{Ali Kırbıyık}

Kayseri çevresinde yetişen halk ozanlarından olan Ali Efendi kalem şairlerindendir. Önder, hocası Hamdi Üçok'un Ali Kırbıyık'1 tanıtmasını istediği için bu yazıyı kaleme aldığını ifade etmiştir. "Tomarzalı Ali Kırbıyık" adlı çalışma, Türk Folklor Araştırmaları dergisinin 248. sayısında yayımlanmıştır. Çalışmada Kırbıyık’ın deyişlerinden örnekler de aktarılmıştır (Önder 1969: 55665568).

\section{Remzi Oğuz Arık}

“Remzi Ŏguz Arık (1899-1954)" adlı çalışma, Filiz dergisinin 1 ve 2. sayılarında yayımlanmıştır. Önder bu yazıyı Arık'ın vefatının on altıncı yıl dönümü dolayısıyla hazırladığını belirtmiştir. Derginin ilk sayısında Türk fikir insanı, 
arkeolog, siyasetçi Arık'ın aile ve çalışma hayatına yer verilmiştir (Önder 1970: 4, 21). İkinci sayıda ise mesleği olan arkeoloji ile ilgili yayımlanmış eserlerinin ve farklı konularda yazmış olduğu çalışmalarının listesi aktarılmıştır (Önder 1970: 4, 22-23).

\section{Ali Sâni Yalçın}

"Ali Sâni Yalçın ve Sâkinamesi" adlı çalışma Filiz dergisinin 5. ve 6. sayılarında yayımlanmıştır. Hamdi Üçok, adı geçen ozanın tanıtılması için kendisine hediye edilen bu Sâkiname'yi Ali Rıza Önder'e vermiştir. Önder ise Kayserili olan bu ozanı tanıtmak ve Kayseri'ye hizmet etmek için bu yazıyı yayımladığını ifade etmiştir. Derginin 5. sayısında yer alan yazıda, ozanın hayatına ve "Sâkiname" başlıklı şiirine yer verilmiştir (Önder 1970: 9,15). Sonraki sayıda ise "Sâkiname"den kalan bölüm aktarılmış ve bilinmeyen kelimeler için sözlük eklenmiştir (Önder 1970: 16-17).

\section{Halim Baki Kunter}

Yeni Adam dergisinin 839. sayısında "Halim Baki Kunter" adı ile yayımlanan yazıda; 5 Nisan 1971 günü vefat eden çok yönlü kültür insanı Halim Baki Kunter'e yer verilmiştir. Önder hazırladığı çalışma ile Kunter'in hayatı, basılan kitapları, çeşitli dergi ve gazetelerde yayımlanmış yazılarının bir kısmı hakkında bilgiler aktarmıştır (Önder 1971: 8,16).

\section{Recai Seçkin}

"Tüze Dilinin Öncüsü Recai Seçkin" adlı çalışma Türk Dili dergisinin 255. sayısında yayımlanmıştır. Önder makalesinde; 17.10.1972 tarihinde vefat eden Yargıtay, Anayasa Mahkemesi, Uyuşmalık Mahkemesi üyesi olan ayrıca hukuk dilinin Türkçeleşmesi ile ilgili çalışmaları bulunan Türk Dil Kurumu onur üyelerinden Recai Seçkin'in eğitimine, çalışma hayatına ve çeşitli görevlerine yer vermiştir (Önder 1972: 290-293).

\section{Fikret Memişoğlu}

"Fikret Memişoğlu (1917-1968)" adlı çalışma, Türk Folklor Araştırmaları dergisinin 286. sayısında yayımlanmıştır. Hukukçu, edebiyat araştırmacısı, halkbilimci Memişoğlu ile Pertek'te birlikte görev yaptıklarına değinen Önder, araştırıcının aile, eğitim ve çalışma hayatına değindikten sonra halkbilim konulu yazılarının künyelerini sunmuştur (Önder 1973: 6642-6643).

\section{2. İshak Sunguroğlu}

Ali Rıza Önder, “Íshak Sunguroğlu” adına Türk Folklor Araştırmaları dergisinin 290. sayısında yer vermiştir. Yazısında, Sunguroğlu'nun aile, eğitim ve değişen meslek hayatına değinmiştir. "Harput Yollarında" adlı dört ciltlik eserinin de konularına kısaca yer vermiştir (Önder 1973: 6754-6755).

\section{Osman Baki Yey}

"Osman Baki Yey (1906-1969)" adlı çalışma Türk Folklor Araştırmaları dergisinin Mayıs 298. sayısında yayımlanmıştır. Önder, yayımlanmış bir eseri ve yazısı 
bulunmayan ancak halkbilim derleyicisi olan Yey'e vefa borcunu ödemek için bu yazıyı kaleme aldığını ifade etmiştir. Ayrıca Yey'in Türk Dil Kurumunda bulunan halkbilimi dosyasından da söz etmiştir (Önder 1974: 6987-6988).

\section{Hasan Eşref Ertekin}

Türk Folklor Araştırmaları dergisinin 303. sayısında "Hasan Eşref Ertekin" adı ile yayımlanan yazıda Çorum'da halkbilim çalışmalarıyla ön plana çıkan Ertekin'in hayatına yer verilmiştir (Önder 1974: 7114-7115).

\section{Ali Ulvi Elöve}

“Ali Ulvi Elöve (1880-1975)" adlı yazı, Yeni Adam dergisinin 890. say1sinda yayımlanmıştır. Yazıda Elöve'nin eğitim, çalışma hayatından ve yayımlanmış eserlerinden söz edilmiştir. Ali Rıza Önder 15 Ağustos 1975 tarihinde vefat eden öğretmen, şair ve dilci Elöve'yi anmayı bir borç olarak gördügünü ifade etmiştir (Önder 1975: 11).

\section{6. İhsan Ozanoğlu}

“Kastamonu'lu İhsan Ozanoğlu” adlı çalışma Türk Folklor Araştırmaları dergisinin 318. sayısında yayımlanmıştır. Önder, âşıklık geleneğinin Kastamonu'daki temsilcilerinden olan İhsan Ozanoğlu'nun aile, eğitim hayatından ve çok yönlü kişiliğinden söz etmiştir. Önder'in çalışmasının bu tarihe rastlamasında Ozanoğlu'nun 10. Âşıklar Bayramında en usta ozan unvanını almasının etkili olduğu anlaşılmaktadır. (Önder 1976: 7543-7545).

\section{Nuh Naci Kum}

Folklor ve Etnografya Araştırmalarında "Nuh Naci Kum” başlı̆̆ı ile 1984 yılında yayımlanan makale, Kum'un vefatının otuzuncu yılına denk gelmektedir. Ali Rıza Önder'in hazırladığ 1 biyografiler içinde en kapsamlı olan çalışmadır. Araştırıcının aile hayatı, eğitimi ve değişen meslek yaşamına yer verilmiştir. Kum'un eserleri ise kitapları ve makaleleri başlığı altında kronolojik olarak sunulmuştur (Önder 1984: 593-600).

\section{Sonuç}

Bir biyograf olarak adlandırdığımız Ali Rıza Önder'in dokuz farklı yayında tespit ettiğimiz kırk yedi biyografi çalışması bulunmaktadır. Bunlardan biyografi zenginliği ile dikkat çeken yayın ise 29 şahsiyet ile Türk Folklor Araştırmaları dergisidir. Adı geçen dergide halkbilimi alanında çalışmalarıyla ön plana çıkan 21 araştırmacı "Folklorcularımız" üst başlığı ile diğer sekiz kişi ise saz şairleri ve tanıtma bölümlerinde Ali Rıza Önder tarafından ele alınmıştır. Türk Folklor Araştırmaları dergisi, 97. sayısından itibaren halkbilimine emek vermiş olanların biyografisini yayınlayacaklarını şu sözlerle duyurmuştur: "Bu sayımızdan itibaren Türk Folklor, Etnoğrafya ve Halk edebiyatına yararlı çalışmaları bulunan değerlerimizin geniş birer biyografisini vermeye başlıyoruz" Dergi bu kararı aldıktan sonra ilk on bir halkbilimci ile ilgili biyografi yazıları belli bir kişi tarafından değil "TFA" adıyla yayımlamıştır. "Vehbi Cem Aşkun" adlı biyografik çalışma ile birlikte bu görevi Ali Rıza Önder'in üstlendiği 
görülmektedir. Diğer yayınlardaki çalışmaların sayısı ise Filiz (6), Erciyes (3), Türk Dili (3), Yeni Adam (2), Folklor ve Etnografya Araştırmaları (1), Türk Düşüncesi (1), İstiklâl Gazetesi (1) ve Hâkimiyet Gazetesi (1) olarak dağılım göstermektedir.

Önder, ele aldığg bu şahsiyetlerin aile, eğitim ve çalışma hayatlarına değinmiş ardından bahsi geçen araştırmacıların eserleri var ise yayım yılları ile çoğunlukla kronolojik olarak vermiştir. İncelediği saz şairlerinin tamamının şiirlerinden bölümler aktarmış bazı araştırmacıların ise eserlerinden alıntılar yapmıştır.

Ali Rıza Önder'in hazırladığı biyografi çalışmalarında ele aldığı şahsiyetler çok yönlü kişiler olduğu için çalışmada herhangi bir meslek tasnifi yapılmamıştır. Ancak şunu diyebiliriz ki hazırlanan bu biyografi çalışmalarında halkbilim, Türk dili ve hukuk alanına hizmet etmiş kişiler çoğunluktadır. Ayrıca bu kırk yedi şahsiyetin on üçünü Kayseri ve çevresinden kişiler oluşturmaktadır. Bu durum da Önder'in memleketi Kayseri'ye hizmetinin, vefasının bir göstergesidir.

Çalışmada bahsi geçen kırk yedi şahsiyetin yayımlandıkları yıllara bakıldığında ise şöyle bir değerlendirme yapılabilir. On üç şahsiyet hakkında, ölümlerinin yıl dönümlerinde ya da vefat ettikleri yıl biyografi çalışmaları hazırlanmıştır. Vehbi Cem Aşkun, Şevket Beysanoğlu, Mehmet Önder, Fahrettin Kırzıoğlu, Hikmet Dizdaroğlu ve Fındıkoğlu Ziyaeddin Fahri adlı biyografilerin hazırlandığı yıl ise bu araştırmacıların kitaplarının yayımlandığı görülmektedir. Bundan hareketle Ali Rıza Önder'in yukarıda adı geçen biyografileri hazırlamasında araştırmacıların yeni çıkan eserlerinin etkisi olduğu değerlendirilebilir.

TFA Ocak 1976 sayısında yayımlanan "Kastamonulu İhsan Ozanoğlu” adlı biyografinin hazırlanması ile Ozanoğlu'nun Ekim 1975 yılında Konya'da düzenlenen 10. Âşıklar Bayramında en usta ozan unvanını alması ile ilişkisi olduğu düşünülmektedir. Bunun yanında Şerif Baykurt'un 1968 yılında Millî Folklor Enstitüsü Müdür Yardımcılığı görevine getirilmesi, Veysel Arseven'in Meydan Larousse adlı ansiklopedide halk müziği ve halk çalgıları maddelerini hazırlaması da yine biyografilerinin hazırlanması için ilişki kurulabilecek gerekçeler olarak görülebilir.

Mustafa İsen başkanlığında yürütülen ve T.C. Kültür ve Turizm Bakanlığı ile Ahmet Yesevi Üniversitesi tarafından desteklenen Türk Edebiyatı İsimler Sözlüğü (TEİS) Projesinin ilki 13. yüzyıldan 20. yüzyıla ikincisi ise 20. yüzyıldan günümüze (1985) kadarki Türk edebiyatında yer alan şair ve yazarları kapsamaktadır. http://teis.yesevi.edu.tr/ adresinden genel ăg ortamında erişilen projenin ikinci aşamasında yer alan Esmer Hatun/Şerife Hala/Şerife Soykan, Osmancıkoğlu/Hamdi Öztosun, Ali Coşkun Huzurî ve İhsan Ozanoğlu maddelerinde Ali Rıza Önder'in hazırladığ 1 bu biyografi çalışmalarından yararlanıldığ1 görülmektedir (Karataş 2018; Çapraz 2018; Çapraz 2019; Pehlivan 2019).

Son söz olarak şunu diyebiliriz ki Ali Rıza Önder'in hazırladığg biyografi çalışmaları; vefat edenleri anma, hayatta olanları ise hatırlama, tanıtma ve onurlandırma amacıyla yazılmıştır. 


\section{Kaynakça}

ÇAPRAZ, Erhan (2018). Osmancıkoğlu.

http://teis.yesevi.edu.tr/madde-detay/osmancikoglu-hamdi-oztosun (E.T.:

24.03.2020)

ÇAPRAZ, Erhan (2019). Şerife Soykan.

http://teis.yesevi.edu.tr/madde-detay/esmer-hatun-serife-hala-serife (E.T.: 24.03.2020)

ÇETİN, Nurullah (2012). Nesir türleri. Ankara: Akçağ Yayınları.

KARATAŞ, Hicran (2018). Ozanoğlu.

http://teis.yesevi.edu.tr/madde-detay/ozanoglu-ihsan-ozanoglu (E.T.: 24.03.2020)

NASRATTINOĞLU, İrfan Ünver (2019). Ali Rıza Önder. Erciyes, 502, 17-19.

ÖNDER, Ali Rıza (1945). Kadın halk şairi Şerife Soykan (1879-1945). Erciyes, 26-27, 15-18.

ÖNDER, Ali Rıza (1946). Halk şairi Osmancıkoğlu. Erciyes, 40-41, 24.

ÖNDER, Ali Rıza (1947). Elbistanlı Âşı1k İmam. Erciyes, 51, 7-8.

ÖNDER, Ali Rıza (1952). Âşık Ali Huzurî Coşkun. Türk Folklor Araştırmaları, 40, 639-640.

ÖNDER, Ali Rıza (1953, 13-14 Ekim). Şeyhülislâm Hayri Efendi. İstiklâl. s. 2.

ÖNDER, Ali Rıza (1956). Hüseyin Kâzım Kadri ve Türkçe sözlüğü. Türk Dili, 53, 54-60.

ÖNDER, Ali Rıza (1957, 20 Şubat). Feramus Uçaravcı. Hâkimiyet. s. 2, 4.

ÖNDER, Ali Rıza (1957). Sadri Maksudî Arsal. Türk Düşüncesi, 7, 52-56.

ÖNDER, Ali Rıza (1957). Ürgüplü Âşık Mahfî. Türk Folklor Araştırmalarl, 99, 1573-1574.

ÖNDER, Ali Rıza (1957). Ürgüplü Memiş Şahin. Türk Folklor Araştırmalart, 105, 1680-1681.

ÖNDER, Ali Rıza (1958). Oğuzlama ve Basri Gocul. Türk Folklor Araştırmaları, 108, 1727-1728.

ÖNDER, Ali Rıza (1959). Kemah'lı Tahir ve divanı. Türk Folklor Araştırmaları, 121, 1969-1970.

ÖNDER, Ali Rıza (1962). Kayseri halkbilimi ve Kâzım Yedekçioğlu. Türk Folklor Araştırmaları, 153, 2687-2688.

ÖNDER, Ali Rıza (1962). Vehbi Cem Aşkun ve çalışmaları. Türk Folklor Araştırmalart, 160, 2887-2888.

ÖNDER, Ali Rıza (1963). Ömer Asım Aksoy. Türk Folklor Araştırmalarl, 165, 3032-3033. 
ÖNDER, Ali Rıza (1964). Şevket Beysanoğlu. Türk Folklor Araştırmaları, 179, 3426-3427.

ÖNDER, Ali Riza (1964). Mehmet Önder ve Konya halkbilimi. Türk Folklor Araştırmalarl, 182, 3514-3516.

ÖNDER, Ali Rıza (1964). Mehmet Fahrettin Kırzığlu. Türk Folklor Araştırmalart, 185, 3595-3597.

ÖNDER, Ali Rıza (1965). Hikmet Dizdaroğlu. Türk Folklor Araştırmaları, 190, 3737-3738.

ÖNDER, Ali Rıza (1965). Betikçi Ali Rıza. Türk Dili, 166, 707-708.

ÖNDER, Ali Rıza (1965). Cahit Öztelli. Türk Folklor Araştırmaları, 193, 38193821.

ÖNDER, Ali Rıza(1965). İsmayıl Hakkı Baltacıŏlu. Türk Folklor Araştırmaları, 196, 3903-3905.

ÖNDER, Ali Riza (1966). Yunus Bekir. Filiz, 16, s. 7, 11.

ÖNDER, Ali Rıza (1966). Öğretmen Galip Öcal. Filiz. 18. s. 3, 9.

ÖNDER, Ali Rıza (1966). Popüler türküler şairi Hasan Turan. Türk Folklor Araştırmalart, 200, 4031-4032.

ÖNDER, Ali Rıza (1966). Abdülkadir Sarıkelle (1875-1946). Filiz, 20. s. 5, 11.

ÖNDER, Ali Rıza (1966). Ahmet Hilmi Kalaç. Filiz, 22. s. 3, 9, 11.

ÖNDER, Ali Rıza (1966). Mustafa Adil Özer. Türk Folklor Araştırmaları, 207, 4214-4215.

ÖNDER, Ali Rıza (1966). Naki Tezel. Türk Folklor Araştırmaları, 209, 42674268.

ÖNDER, Ali Rıza (1967). Ord. Prof. Dr. Fındıkoğllu Ziyaeddin Fahri. Türk Folklor Araştırmaları, 212, 4353-4355.

ÖNDER, Ali Rıza (1967). Ahmet Kutsi Tecer. Türk Folklor Araştırmaları, 218, 4515-4517.

ÖNDER, Ali Rıza (1968). Ahmet Şükrü Esen (1893-1944). Türk Folklor Araştırmalarl, 222, 4631-4633.

ÖNDER, Ali Rıza (1968). Veysel Arseven. Türk Folklor Araştırmaları, 232, 5120-5122.

ÖNDER, Ali Rıza (1969). Şükrü Elçin. Türk Folklor Araştırmaları, 236, 52325233.

ÖNDER, Ali Rıza (1969). Şerif Baykurt. Türk Folklor Araştırmaları, 245, 54755476.

ÖNDER, Ali Rıza (1969). Tomarzalı Ali Kırbıyık. Türk Folklor Araştırmaları, 248, 5566-5568. 
ÖNDER, Ali Rıza (1970). Remzi Oğuz Arık (1899-1954). Filiz, 1, s. 4, 21.

ÖNDER, Ali Rıza (1970). Remzi Oğuz Arık (1899-1954) II. Filiz, 2, s. 4, 22-23.

ÖNDER, Ali Rıza (1970). Ali Sâni Yalçın ve sâkinamesi. Filiz, 5, s. 9, 15.

ÖNDER, Ali Rıza (1970). Ali Sâni Yalçın ve sâkinamesi. Filiz, 6, 16-17.

ÖNDER, Ali Riza (1971). Halim Baki Kunter. Yeni Adam, 839. s. 8, 16.

ÖNDER, Ali Rıza (1972). Tüze dilinin öncüsü Recai Seçkin. Türk Dili, 255, 290293.

ÖNDER, Ali Rıza (1973). Fikret Memişoğlu (1917-1968). Türk Folklor Araştırmalarl, 286, 6642-6643.

ÖNDER, Ali Rıza (1973). İshak Sunguroğlu. Türk Folklor Araştırmaları, 290, 6754-6755.

ÖNDER, Ali Rıza (1974). Osman Baki Yey (1906-1969). Türk Folklor Araştırmalarl, 298, 6987-6988.

ÖNDER, Ali Rıza (1974). Hasan Eşref Ertekin. Türk Folklor Araştırmaları, 303, 7114-7115.

ÖNDER, Ali Rıza (1975). Ali Ulvi Elöve (1880-1975). Yeni Adam, 890, 11.

ÖNDER, Ali Rıza (1976). Kastamonulu İhsan Ozanoğlu. Türk Folklor Araştırmalarl, 318, 7543-7545.

ÖNDER, Ali Rıza (1984). Nuh Naci Kum. Folklor ve Etnografya Araştırmaları. İstanbul: Anadolu Sanat Yayınları.

PEHLIVAN, Gürol (2019). Huzurî.

http://teis.yesevi.edu.tr/madde-detay/huzuri-ali-coskun (E.T.: 24.03.2020)

TAN, Nail (2019). Ali Rıza Önder ve Türk Dil Kurumu. Erciyes, 502, 28-29.

TÜRK EDEBIYYATI İSIMLER SÖZLÜĞÜ, http://teis.yesevi.edu.tr/ (E.T.: 24.03.2020)

TÜRKÇE SÖZLÜK (2005). Ankara: Türk Dil Kurumu Yayınları. 